\title{
Status Konservasi Sarang Megapoda Arfak (Aepypodius arfakianus) di Cagar Alam Pegunungan Arfak: Salah satu dampak dari perubahan lansekap
}

\author{
Ikram Karim¹, Lukas Yowel Sonbait ${ }^{1}$, Freddy Pattiselanno ${ }^{1,2}$ \\ ${ }^{1}$ Jurusan Peternakan, Fakultas Peternakan Universitas Papua \\ 2Pusat Penelitian Keanekaragaman Hayati Universitas Papua; e-mail: f.pattiselanno@unipa.ac.id
}

\begin{abstract}
ABSTRAK
Tingkat pemanfaatan Megapoda Arfak (Aepypodius arfakianus) oleh masyarakat melalui perburuan dan pengumpulan telur cukup tinggi. Hal ini berdampak terhadap status populasi burung ini di alam. Penelitian tentang status konservasi sarang Megapoda Arfak telah dilakukan untuk mengetahui kondisi sarang yang memungkinkan perkembangan populasi burung ini. Pengumpulan data dilakukan pada tanggal 22 sampi 27 Mei 2016 dan 14 sampai 19 Juni 2016 di Kampung Sigim, sekitar kawasan Cagar Alam Pegunungan Arfak. Metode deskripsi dengan teknik survei dan pengamatan (observasi) langsung digunakan dalam pengumpulan data di lokasi penelitian. Dari sembilan sarang yang ditemukan dan diamati, enam sarang jaraknya relatif dekat dari pemukiman atau berjarak kurang dari $1.0 \mathrm{~km}$ sehingga mendapat tekanan perburuan dan pengumpulan telur yang lebih berat. Berdasarkan statusnya, dua sarang berstatus ditinggalkan dan empat sarang memiliki status terancam. Tiga sarang lainnya yang berjarak $2-3 \mathrm{~km}$ dari pemukiman berstatus tidak terancam. Konsekuensi dari konversi luasan hutan untuk tujuan lainnya (pembangunan sarana dan pra-sarana public seperti pengembangan ruas jalan dan pembangunan pemukiman) serta pembukaan lahan perkebunan dan pertanian memberikan kemudahan akses ke lokasi persarangan Megapoda Arfak. Hal ini berdampak terhadap status konservasi sarang, karena perburuan burung dan pengumpulan telur yang tidak terkendali.
\end{abstract}

Kata kunci: Status konservasi, sarang, Megapoda Arfak

\begin{abstract}
High level of Arfak Megapode (Aepypodius arfakianus) exploitation -through hunting and egg collection affects the population status of this species in their habitat. Research on conservation status of Arfak Megapode's nesting ground was carried out to have better understanding on nesting ground condition with regard to keep the population increased in their habitat. Data ceollection was conducted between 22-27 May and 14-19 June 2016 in Sigim a village around the Mountain Arfak Nature Reserve. Descriptive methods with survey and direct observation in the field were used to collect the information. From nine nests found and observed, six of them were relatively close from the settlement or about less than $1 \mathrm{~km}$, thus received severe hunting pressure and egg collecting. Based on their status, two nests were abandoned and four were threatened. The other three nests approximately $2-3 \mathrm{~km}$ from the settelements were not threatened. As a consequence of forest conversion for other purposes (public infrastructure development such as road development and setlements constructed), modern plantations create easy access to the nesting grounds of Arfak Megapode. This creates significant impact on the conservation status of the nesting grounds, because of uncontrolled hunting and egg collecting.
\end{abstract}

Keywords: Conservation status, nest, Arfak Megapode

Citation: Karim, I., Sonbait, Y.L., dan Pattiselanno, F. (2020). Status Konservasi Sarang Megapoda Arfak (Aepypodius arfakianus) di Cagar Alam Pegunungan Arfak. Jurnal Ilmu Lingkungan, 18(1), 119-125, doi:10.14710/jil.18.1.119-125

\section{Pendahuluan}

Megapoda adalah salah satu kelompok burung endemik di beberapa daerah di Indonesia. Dari 22 spesies Megapoda yang ada, Jones et al. (1995) menjelaskan bahwa 17 spesies berada di Papua dan lima diantaranya adalah endemic yaitu: Talegalla cuvieri, Talegalla jobiensis, Talegalla fuscirostris, Aepypodius arfakianus, Aepypodius bruijnii (Petocz, 1987).
Menurut Jones et al (1995), Maleo gunung, Maleo Arfak atau Megapoda Arfak (Aepypodius arfakianus) adalah megapoda endemik Papua dengan habitat utamanya di dalam dan sekitar kawasan Cagar Alam Pegunungan Arfak (CAPA). Pemanfaatan Megapoda Arfak oleh masyarakat cukup tinggi, dibuktikan dari hasil penelitian Triyantoro (2002), bahwa rata-rata masyarakat mengkonsumsi 9 ekor/KK/bulan, sedangkan pemanfaatan telur rata - rata 4 
Karim, I., Sonbait, Y.L., dan Pattiselanno, F. (2020). Status Konservasi Sarang Megapoda Arfak (Aepypodius arfakianus) di Cagar Alam Pegunungan Arfak. Jurnal IImu Lingkungan, 18(1), 119-125, doi:10.14710/jil.18.1.119-125

butir/KK/musim. Menurut Lindongi (2002) pada musim bertelur Februari dan Agustus penjualan telur Maleo di Pasar Wosi, Manokwari cukup tinggi. Manik (2008), menjelaskan bahwa perburuan spesies ini untuk mendapatkan daging dan telurnya oleh masyarakat menggunakan senjata api, jerat serta penggalian terhadap sarang.

Megapoda Arfak membangun sarang berbentuk gundukan besar secara mencolok, untuk menetaskan telurnya melalui alternatif sumber panas dari pembusukan material seperti daun dan ranting (Jones \& Birks, 1992). Karena penampakan yang menonjol, sarang mudah dideteksi pemburu. Selain itu dikhawatirkan tersedianya akses ke lokasi persarangan akan memicu pemanfaatan telur dan perburuan burung yang tidak terkendali di habitat alaminya. Hal ini akan berdampak buruk terhadap kondisi populasi yang mengarah kepada kepunahan spesies burung tersebut (Argeloo \& Dekker, 1996).

Masalah utama yang dihadapi dalam usaha pelestarian Megapoda adalah penurunan populasi yang sangat tajam hampir di semua tipe habitat akibat dari eksploitasi terhadap telur, degradasi hutan dan fragmentasi habitat (Baker \& Butchart, 2000). Selanjutnya Gorog at al. (2005) melaporkan bahwa akibat pengrusakan terhadap habitat Megapoda, berdampak terhadap populasi burung tersebut di alam. Jika kondisi ini dibiarkan terus menerus dan tidak ditangani secara serius maka kemungkinan besar populasinya akan terancam pada habitat alaminya.

Sejalan dengan program pembangunan di Kabupaten Pegunungan Arfak, konversi luasan hutan yang merupakan bagian dari kawasan Cagar Alam Pegunungan Arfak (CAPA) (Pattiselanno, 2016), guna menyediakan sarana dan pra-sarana pemerintahan seperti perkantoran, pemukiman, lahan pertanian dan perkebunan, jalan, jembatan serta sarana lainnya (Pattiselanno \& de Fretes, 2016) diperkirakan merupakan salah satu penyebab hilangnya habitat alami Megapoda Arfak. Terbukanya akses dan konversi sejumlah luasan hutan di sisi lain menyediakan kemudahan akses bagi para pemburu untuk mencapai lokasi sarang dan melakukan eksploitasi yang tidak terkendali (Pattiselanno \& Arobaya, 2015). Oleh karena itu intensitas pemanfaatannya ikut meningkat dan mempengaruhi jumlah populasinya di habitat alaminya.

Diasumsikan bahwa areal persarangan yang dekat dengan pemukiman dan mudah diakses masyarakat mengalami tekanan yang lebih besar akibat pengambilan telur dan perburuan burung oleh pemburu dibanding dengan lokasi sarang yang jauh dari pemukiman. Apakah dugaan ini benar? Hal ini perlu dikaji lebih lanjut. Selain itu, penilaian status konservasi sarang Megapoda Arfak (Aepypodius arfakianus) di habitat alaminya di sekitar Kawasan CAPA perlu dilakukan untuk mengetahui seberapa besar tekanan perburuan akibat semakin terbukanya akses yang berdampak terhadap status konservasi sarangnya. Oleh karena itu penelitian ini bertujuan untuk menilai status konservasi sarang Megapoda Arfak (Aepypodius arfakianus) sebagai dampak dari perubahan lansekap di sekitar wilayah penelitian.

\section{Metode Penelitian}

Penelitian ini dilakukan selama 2 minggu, yaitu pada tanggal 22 sampai 27 Mei 2016 dan 14 sampai 19 Juni 2016. Tempat penelitian yaitu di Kampung Sigim, Distrik Minyambouw, sekitar kawasan Cagar Alam Pegunungan Arfak.

Penelitian menggunakan metode deskriptif melalui survei dan mewawancarai masyarakat setempat untuk mendapatkan informasi tentang lokasi peneluran dan kondisi lingkungan sekitarnya. Pengamatan (observasi) langsung di lapangan juga dilakukan untuk melakukan penilaian status konservasi sarang menurut Argeloo (1994) dan Dekker (1990) seperti pada Tabel 1.

Di setiap lokasi ditemukannya sarang dilakukan pengambilan titik georeferenced menggunakan GPS untuk memetakan lokasi sarang, selanjutnya diberi tanda menggunakan pita berwarna sebagai penanda lokasi sarang.

Sarang yang diteliti tergantung pada jumlah sarang yang ditemukan selama penelitian, semakin banyak semakin baik, dengan jumlah minimal 5 (lima) sarang (Pattiselanno \& Arobaya, 2014).

Variabel utama dalam penelitian ini adalah status konservasi sarang dengan mengacu pada kriteria Argeloo (1994) dan Dekker (1990) pada Tabel 1. Sedangkan variable pendukung adalah jarak areal persarangan dari kampung mengacu pada titik georeferenced dan profil sarang (tinggi dan diameter) sarang yang ditemukan, serta pencatatan terhadap vegetasi yang ditemukan di sekitar sarang akan digunakan untuk melengkapi kondisi sarang.

\section{Hasil dan Pembahasan}

\subsection{Status Konservasi Sarang}

Pengamatan terhadap saranag Maleo gunung (n = 9) di Kampung Sigim dengan mengacu pada kriteria penilaian status konservasi sarang yang digunakan Argeloo (1994) dan Dekker (1990) pada Tabel 1, disajikan dalam Tabel 2.

Data di lapangan menunjukan bahwa tidak ada sarang yang terancam parah tetapi sarang dengan status terancam ditemukan dalam persentase terbesar, diikuti dengan belum terancam dan ditinggalkan. Sarang yang kondisinya terancam (Gambar 1) masih sering dikunjungi burung dan selama penelitian. Tercatat bahwa sarang tersebut 
Tabel 1. Kriteria Untuk Penilaian Status Konservasi Lokasi Peneluran Maleo (Argeloo, 1994; Dekker, 1990)

\begin{tabular}{ll}
\hline \multicolumn{1}{c}{ Status } & \multicolumn{1}{c}{ Kriteria } \\
\hline Ditinggalkan & Tidak ada telur dalam sarang saat diamati \\
Terancam parah & Hanya sedikit saja burung yang memanfaatkan lokasi tersebut, dan kemungkinan akan ditinggalkan \\
& dalam beberapa waktu ke depan \\
Terancam & Lokasi peneluran masih sering digunakan untuk penetasan, tetapi kemungkinan keamanannya akan \\
& terganggu dalam waktu dekat karena pengumpulan telur yang intensif, pengembangan wilayah atau \\
& keduanya \\
Belum terancam & Lokasi sarang masih dalam kondisi baik dan sangat mudah diakses oleh burung Maleo dengan \\
& kehadiran pengumpul yang sangat kurang atau sama sekali tidak ada \\
\hline \hline
\end{tabular}

Tabel 2. Status Konservasi Lokasi Peneluran Maleo di Kampung Sigim

\begin{tabular}{lcc}
\hline \multicolumn{1}{c}{ Status } & Jumlah Sarang & Persentase (\%) \\
\hline Ditinggalkan & 2 & $22,22 \%$ \\
Terancam parah & 0 & 0 \\
Terancam & 4 & $44,44 \%$ \\
Belum terancam & 3 & $33,33 \%$ \\
\hline \hline
\end{tabular}

dikunjungi selama empat kali oleh dua sampai tiga ekor burung secara bergantian dalam sekali kunjungan.

Sarang yang belum terancam ditemukan masih dalam kondisi yang baik dan utuh, dilindungi oleh vegetasi sekitar yang masih dalam kondisi tidak terganggu (Gambar 2). Terlihat ada bekas tapak kaki burung dari berbagai arah dan aktivitas masih terdeteksi di sarang dengan melihat timbunan daun, ranting dan metrial lain yang berfungsi sebagai

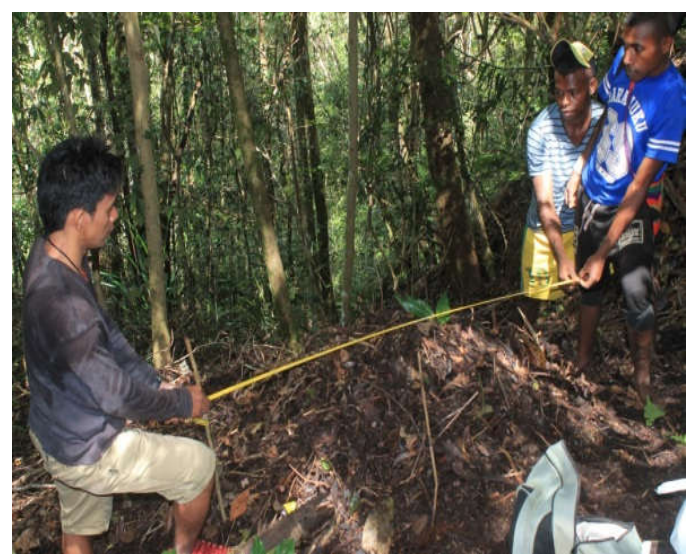

sumber panas untuk penetasan telur. Kami juga mencatat bahwa hampir setiap hari ada burung yang mengunjungi sarang tersebut.

Sarang yang ditinggalkan umumnya berada dalam kondisi terbengkalai, tidak terdapat tandatanda dikunjungi, karena sama sekali tidak ditemukan aktivitas di sekitar sarang tersebut. Kondisi sarang telah rusak dan tidak tampak kehadiran burung di lokasi sekitar sarang tersebut (Gambar 3).

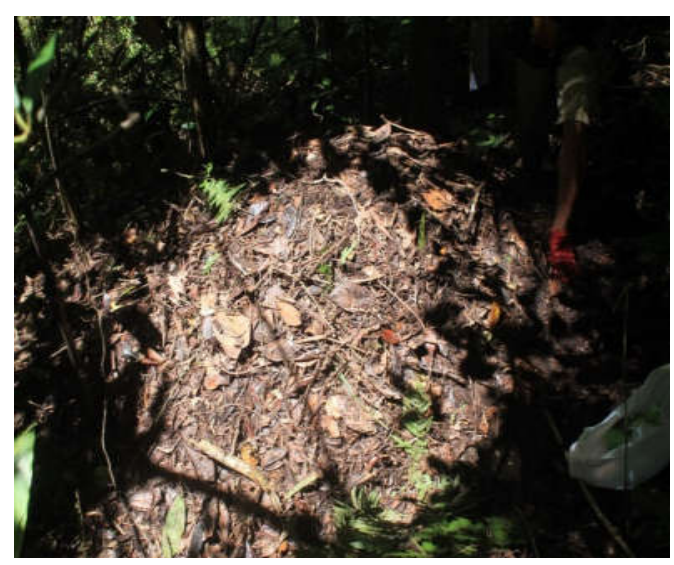

Gambar 1. Kondisi sarang terancam
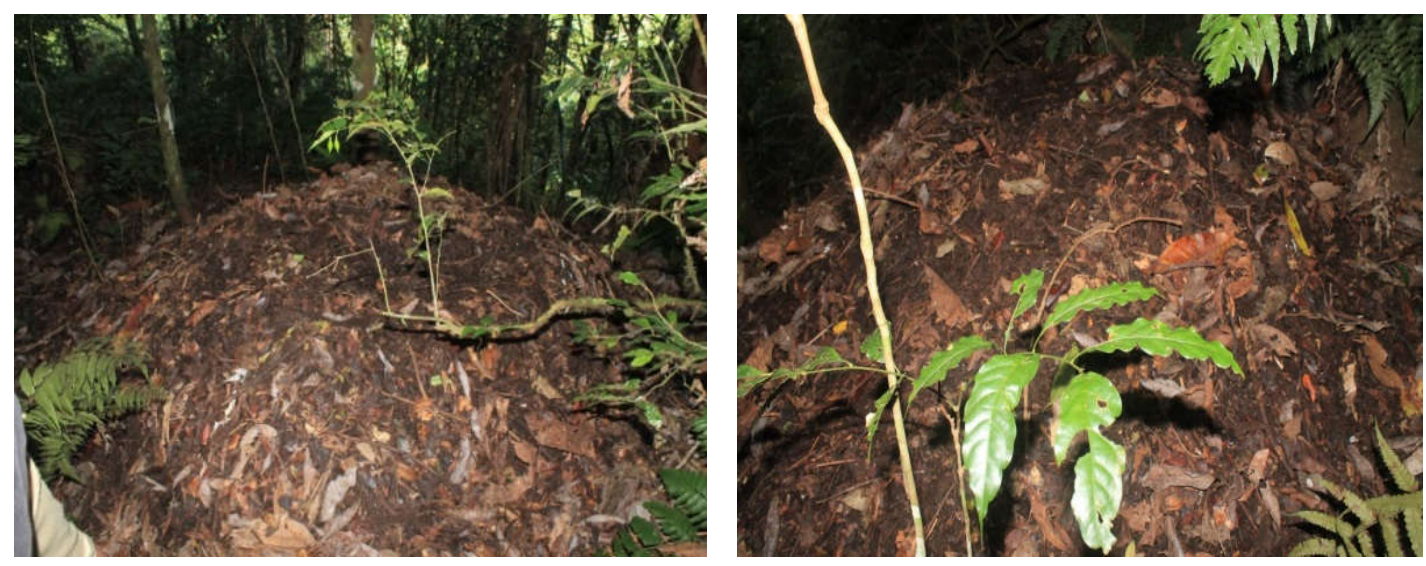

Gambar 2. Kondisi sarang yang belum terancam 

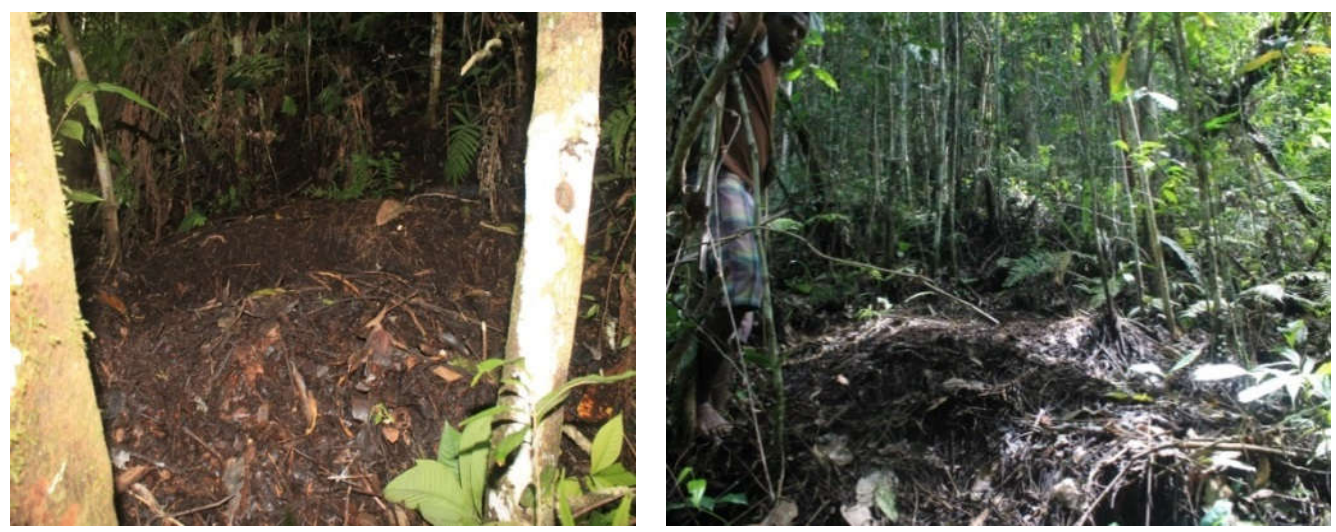

Gambar 3. Kondisi sarang yang ditinggalkan

\subsection{Jarak sarang dan status konservasinya}

Penyebaran 9 (sembilan) sarang yang ditemukan saat penelitan disajikan dalam Gambar 4. Jumlah sarang yang ditemukan terdiri dari 6 (enam) sarang yang dekat atau kurang dari satu kilometer $(<1 \mathrm{~km})$ dengan variasi jarak antara 0.7 sampai dengan $1.0 \mathrm{~km}$ dari kampung (titik merah pada gambar). Keenam sarang yang dekat dengan kampung diidentifkasi sebagai sarang dengan status ditinggalkan ada dua sarang $(22,22 \%)$ dan status terancam ada empat sarang $(44,44 \%)$. Ada juga 3 (tiga) sarang yang ditemukan jauh (titik biru pada gambar) atau lebih dari satu kilometer $(>1 \mathrm{~km})$ dengan variasi jarak (2-3 $\mathrm{km})$ dari kampung. Semua sarang yang letaknya jauh dari kampung $(33,33 \%)$ berada dalam status belum terancam.

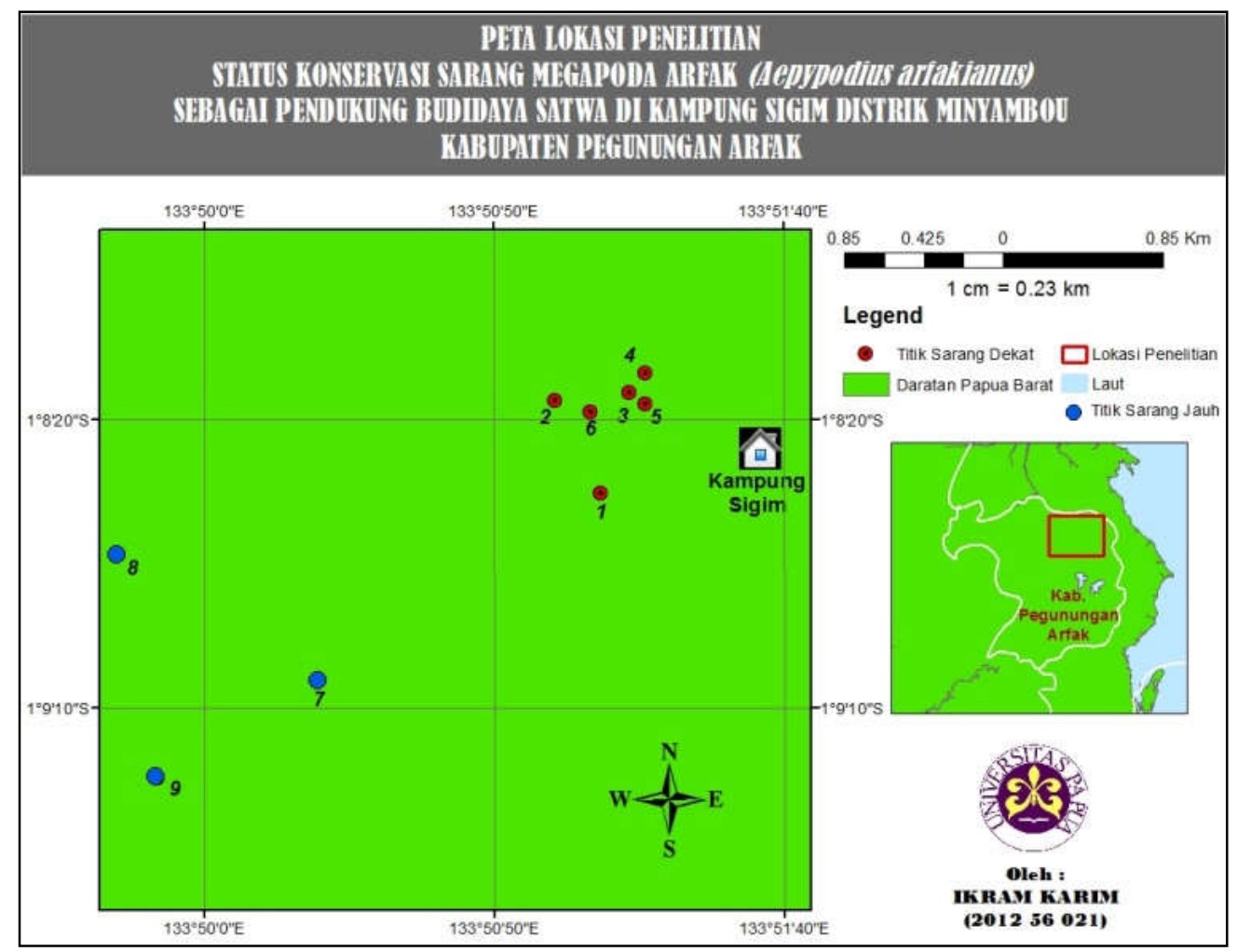

Gambar 4. Peta Lokasi Penelitian dan keberadaan sarang yang ditemukan

Dari sembilan sarang yang ditemukan, ada enam sarang yang ditemukan kurang dari satu kilometer jaraknya dari kampung Sigim. Jika dilihat status konservasi keenam sarang ini masing-masing dua sarang berstatus ditinggalkan dan empat sarang berstatus terancam, maka dapat dipastikan bahwa kemudahan akses terhadap sarang yang dekat dengan pemukiman menyebabkan status konservasinya terancam dan ditinggalkan. Hal mana didukung dengan pengakuan masyarakat setempat pada saat diwawancarai, bahwa sarang yang dekat dengan kampung merupakan sarang yang sering dikunjungi oleh masyarakat untuk melakukan perburuan terhadap telur pada musim bertelur. Sedangkan perburuan Maleo dilakukan bukan pada saat musim bertelur.

Diduga sarang yang statusnya terancam disebabkan karena perburuan burung dan 
pengumpulan telur oleh masyarakat yang tidak terkendali dengan cara memasang jerat di sekitar sarang (Gambar 5). Kemudahan akses yang tersedia ke lokasi sarang menjadi penyebab utama, misalnya pembukaan lahan untuk kebun oleh masyarakat (Gambar 6) dan pegembangan ruas jalan, yang merusak habitat alami Megapoda Arfak ini. Kondisi ini pada akhirnya mempengaruhi status konservasi sarang yang berdampak terhadap kehadiran burung di sarangnya.

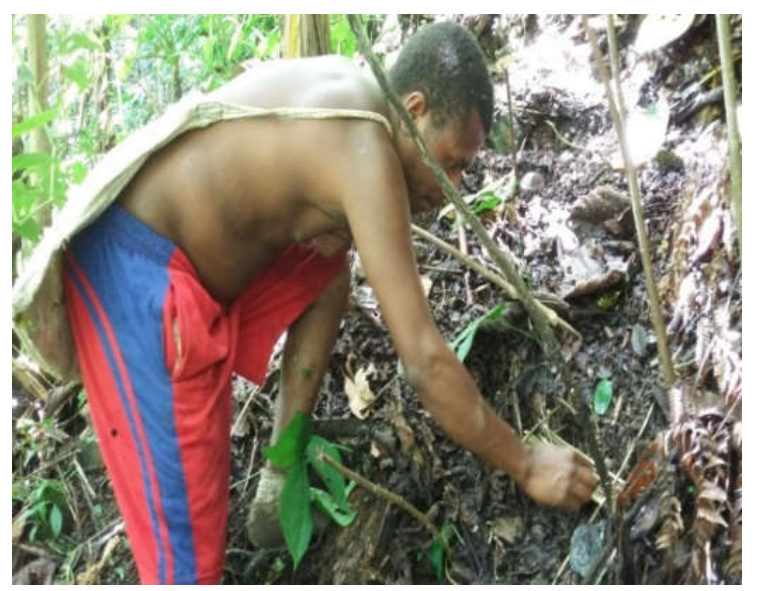

Gambar 5. Pemasangan jerat di sarang aktif oleh pemburu

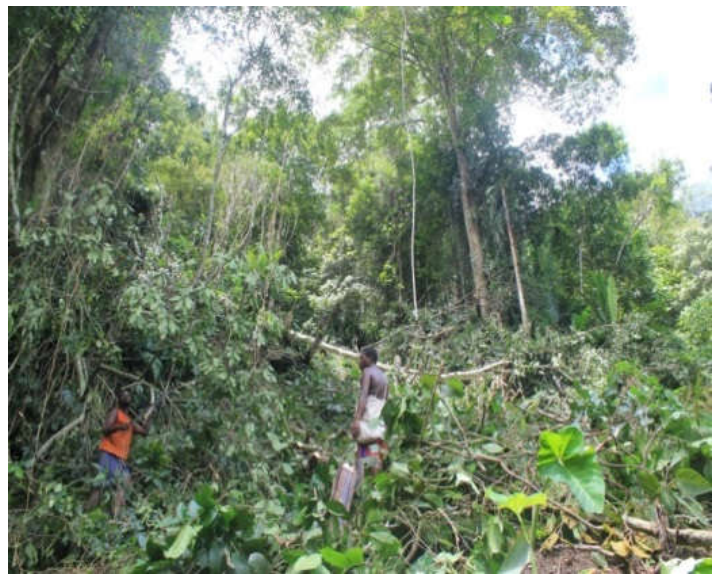

Gambar 6. Pembersihan areal untuk pembukaan lahan perkebunan/pertanian

\subsection{Ancaman terhadap konservasi sarang}

Dalam sekali periode berburu (dalam seminggu, perburuan dilakukan tiga kali) kelompok masyarakat di Kampung Sigim, dapat menangkap 10-20 ekor burung. Perburuan burung ini dilakukan di luar musim bertelur. Dalam satu bulan, diprediksikan jumlah burung yang diburu oleh kelompok masyarakat di kampung Sigim berkisar antara 40-80 ekor.

Pengumpulan telur di Sigim, hanya dilakukan pada musim bertelur, dengan jumlah sekitar 50-100 butir per musim bertelur. Satu musim bertelur bervariasi di antara spesies Megapoda, dan menurut informasi dari masyarakat periode bertelur Megapoda Arfak antara bulan Agustus dan Desember. Dekker dan Wattel (1987) menjelaskan bahwa untuk
Macrocephalo maleo musim bertelur biasanya antara bulan Juni dan September. Hasil ini sekaligus memberikan gambaran bahwa periode bertelur yang cukup panjang membuka peluang terhadap pemanfaatan yang berdampak terhadap keberhasilan penetasan telur dan populasi Megapoda Arfak di alam saat ini.

Konversi luasan hutan menjadi areal pertanian dan perkebunan modern dan aktivitas lainnya seperti konsesi hutan, pertambangan, pemukiman, jalan dan prasarana publik lainnya (Gambar 7), menjadi penyebab degradasi sejumlah habitat alami Maleo (Dekker, 1994; Argeloo \& Dekker, 1996; Baker \& Butchart, 2000). Jika kondisi seperti ini terus berlanjut, maka sejumlah areal persarangan akan ditinggalkan di waktu mendatang.

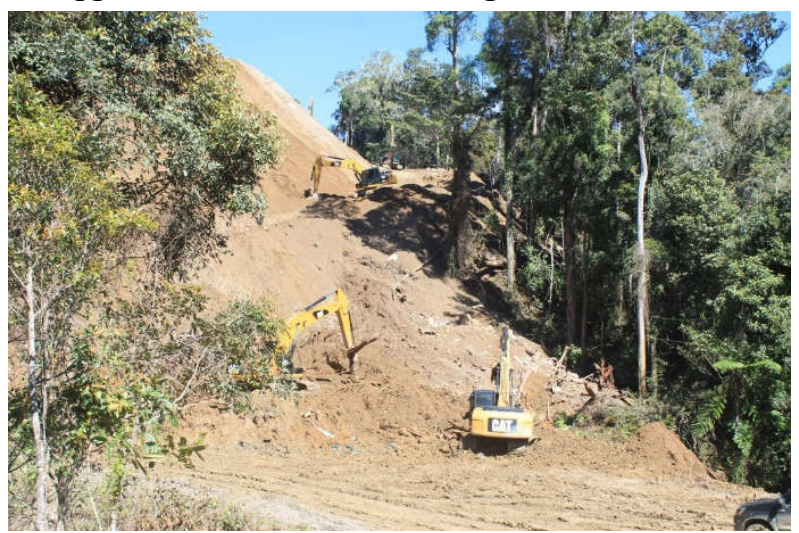

Gambar 7. Konversi hutan untuk pengembangan ruas jalan yang membelah kawasan Cagar Alam Pegunungan Arfak (CAPA)

Laporan Argeloo (1994) menunjukan bahwa kegiatan pengumpulan telur secara teratur maupun tidak terencana secara signifikan mengancam kondisi areal sarang sebagai lokasi peneluran Maleo. Areal yang dekat dengan lokasi pemukiman, sangat terancam akibat kegiatan pengumpulan telur yang tidak terkendali dan sebagian besar sudah ditinggalkan (Baker \& Butchart, 2000).

Meningkatnya aktivitas manusia di sekitar habitat satwa memberikan dampak yang kurang baik khususnya bagi kelompok satwa yang sensitif (Steidl \& Anthony, 2000). Hasil beberapa penelitian yang pernah dilakukan menunjukkan bahwa tingkat aktivitas (intensitas) manusia yang berbeda menjadi faktor yang berdampak terhadap kehadiran satwa tertentu pada habitat alaminya baik dalam jangka waktu singkat maupun panjang (Steidl \& Anthony 2000; Swarthout \& Steidl 2003; Mann et al. 2002; Johnson et al. 2005)

Karena jaraknya yang dekat dengan pemukiman intensitas kunjungan pemburu ke lokasi sarang cukup tinggi yaitu 3 hari setiap minggu. Enam sarang yang dekat dengan kampung merupakan sarang yang sering dikunjungi oleh masyarakat untuk melakukan perburuan burung dan pengumpulan telur pada musim bertelur. Sarang-sarang ini menerima tekanan perburuan yang cukup tinggi sehingga resiko gagal dalam menjaga dan meningkatkan populasi burung sangat tinggi. Berbeda dengan pengumpulan telur, 
perburuan burung Maleo dilakukan diluar musim bertelur.

Di sisi lain terbukanya sejumlah areal sekitar sarang akibat konversi hutan ke peruntukan lainnya memberikan kemudahan akses bagi masayarakat ke lokasi persarangan. Hanya diperlukan waktu berjalan selama kurang lebih 15 sampai 20 menit atau dengan jarak perjalanan kurang lebih 0,7 kilometer dari pemukiman ke areal sarang. Oleh karena itu sarangsarang yang dekat dengan pemukiman menerima tekanan perburuan burung dan pengumpulan telur yang berat.

Tekanan perburuan sering berasosiasi dengan kemudahan akses pemburu dan pengumpul ke areal hutan yang belum terganggu sebagai akibat berkembangnya jalan dan fragmentasi hutan juga merupakan factor yang mempengaruhi eksploitasi satwa (Robinson \& Bennett, 2000; Milner-Gulland et al., 2003; Refisch \& Koné, 2005 and Fa et al., 2005). Terbukanya akses jalan bukan hanya membawa para pemburu lebih dekat ke areal perburuan, tetapi juga membuka hubungan antara sumber daya secara langsung dengan pasar (Robinson et al., 1999). Peningkatan jalan trans Sulawesi yang menghubungkan Sulawesi Utara dengan provinsi lainnya seperti Gorontalo dan Sulawesi Tengah memicu peningkatan importasi daging satwa untuk menjawab kebutuhan pasar (Lee, 2000).

Sarang dengan status belum terancam $(33,33 \%)$ semuanya berjarak jauh dari kampung. Hampir setiap hari sarang tersebut masih aktif dikunjungi oleh satu hingga dua ekor Megapoda Arfak selama periode pengamatan. Kondisi sarang aktif juga ditandai dengan lantai hutan disekitar sarang relatif bersih, hal ini diakibatkan karena adanya aktifitas mengais yang dilakukan ketika mempersiapkan sarang (Panggur, 2008). Selain itu, sarang yang masih aktif ditunjukan dengan gundukan sarang yang masih utuh juga komposisi daun penyusun sarang sebagian besar masih dalam keadaan baik dan utuh (Pattiselanno, 2005, Manik, 2008).

Kondisi ini juga sekaligus menggambarkan proses penyiapan sarang oleh Megapoda Arfak untuk musim bertelur yang akan datang. Informasi yang diperoleh dari wawancara dengan masyarakat, ternyata bahwa musim bertelur burung Megapoda Arfak yaitu bulan antara bulan Agustus dan Desember. Di Pulau Buru, jenis megapoda lainnya Gosong Kelam, bertelur pada bulan Februari-Maret, di Seram pada bulan Mei (Tuhumury, t.t) dan Agustus-November di Pulau Komodo (Panggur, 2008). Menurut del Hoyo (1994) yang disitasi oleh Panggur (2008) menyatakan bahwa di Papua Nugini musim bertelur terjadi pada pertengahan November-Mei, pada saat dan setelah hujan.

Secara geografis sarang yang belum terancam ini lokasinya jauh dari pemukiman dengan jangkauan jarak berjalan kaki kurang lebih 3 sampai 4 jam dari kampung atau sekitar $3 \mathrm{~km}$ tergantung kondisi topografi setempat. Pengakuan masyarakat, sarang ini hanya dikunjungi pada saat musim burung bertelur, karena membutuhkan waktu yang cukup lama untuk mencapai lokasi sarang. Frekuensi berkunjung yang tidak terlalu intensif karena jarak sarang yang jauh dari pemukiman memberikan peluang yang cukup besar bagi Megapoda Arfak untuk untuk tetap meletakan telurnya untuk ditetaskan.

\section{Kesimpulan}

Dari sembilan sarang yang ditemukan dan diamati, enam sarang jaraknya relatif dekat dari pemukiman atau kurang dari $1.0 \mathrm{~km}$ sehingga mendapat tekanan perburuan dan pengumpulan telur yang lebih berat. Berdasarkan statusnya, dua sarang berstatus ditinggalkan dan empat sarang memiliki status terancam. Tiga sarang lainnya yang berjarak 2$3 \mathrm{~km}$ dari pemukiman berstatus tidak terancam. Konsekuensi dari konversi luasan hutan untuk tujuan lainnya (pembangunan sarana dan pra-sarana public seperti pengembangan ruas jalan dan pembangunan pemukiman) serta pembukaan lahan perkebunan dan pertanian memberikan kemudahan akses ke lokasi persarangan Megapoda Arfak. Hal ini berdampak terhadap status konservasi sarang, karena perburuan burung dan pengumpulan telur yang tidak terkendali.

\section{DAFTAR PUSTAKA}

Argeloo, M. and Dekker, R.W.R.J. 1996. Exploitation of megapode eggs in Indonesia: the role of traditional methods in the conservation of megapodes. Oryx 30(1): 59-64

Argeloo, M. 1994. The Maleo Macrocephalon maleo: New information on the distribution and status of Sulawesi's endemic megapode. Bird Conservation International 4:383-393.

Baker, G.C. and Butchart, S.H.M. 2000. Threats to maleo Macrocephalon maleo and recommendations for its conservation. Oryx 34: 255-261

Dekker, R.W.R.J. 1990. The distribution and status of nesting ground of the Macrocephalon maleo in Sulawesi, Indonesia. Biological Conservation Journal (51) : 139 150

Fa JE, Ryan SF, Bell DJ. 2005. Hunting vulnerability, ecological characteristics and harvest rates of bushmeat species in Afrotropical forests. Biological Conservation 121, 167-176

Gorog, A.J., Pamungkas, B, and Lee, J.L. 2005. Nesting Ground Abandoment by The Maleo (Macrocephalon maleo) in North Sulawesi: Identiffying Conservation Priorities for Indonesia's Endemic Megapode. Biological Conservation Journal.Vol.126 (4):548-555

Johnson, C.J., Boyce, M.S., Case, R.L., Cliff, H.D., Gau, R.J., Gunn, A. and Mulders, R. 2005. Cumulative effects of human developments on arctic wildlife. Wildl Monographs 160.

Jones, D.N., Dekker, R.W.R.J. and Roselaar, C.S. 1995. Bird Families of The World: The Megapode. Oxford University Press. Oxford.

Jones, D.N. and Birks, S. 1992. Megapodes: recent ideas and origins, adaptations and reproduction. Trends on Ecology and Evolution 7: 88-91 
Lee, R.J. 2000. Impact of subsistence hunting in North Sulawesi, Indonesia and conservation options. In J.G. Robinson\& E.L. Bennett (Eds.), Hunting for Sustainability in Tropical Forests. (pp. 455-472) New York: Columbia University Press.

Lindongi, J.C. 2002. Ekologi Persarangan Burung Maleo (Megapodius freycinet) Pada Areal Hutan Bremi Kabupaten Manokwari. Skripsi.Universitas Negeri Papua, Manokwari

Manik, H. 2008. Ekologi Persarangan Burung Maleo Gunung (Aepypodius arfakianus) pada areal Aliran Kali Mokwam KabupatenManokwari Papua Barat. Jurnal Ilmu Peternakan. Vol 3 (2): 101-106.

Mann, S.L., Steidl, R.J. and Dalton, V.M. 2002. Effects of cave tours on breeding cave myotis. J. of Wildl Manag. 66: 618-624.

Panggur, M.R. 2008. Karakteristik Gundukan Bertelur Dan Perilaku Bertelur Burung Gosong Kaki-Merah (Megapodius reinwardt Dumont 1823) di Pulau Rinca, Taman Nasional Komodo. Skripsi. Fakultas Kehutanan Institut Pertanian Bogor

Pattiselanno, F. and de Fretes, Y. 2016. Potency and distribution of Papua's terrestrial biodiversity. International Conference on Biodiversity, Ecotourism and Creative Economy, 7-10 September, Jayapura, Papua.

Pattiselanno, F. 2016. Menginisiasi pembangunan jalan dalam kawasan lindung. Media Papua 4 Oktober 2016

Pattiselanno, F, and Arobaya, A.Y.S. 2015. Road development versus conservation. Jakarta Post, 21 May 2015

Pattiselanno, F. and Arobaya, A.Y.S. 2014. Components, ground temperature and status of incubation mounds of Megapode freycinet Gaimard in Rumberpon Island. Tigerpaper 41(3): 15-20

Pattiselanno, F. 2005. Characteristic of Dusky Megapode's nesting grounds in the coastal area of Rumberpon
Island, West Papua, Indonesia. Tigerpaper 32(3): 2023

Pattiselanno, F. 2000. Perbandingan Karakteristik Sarang Megapoda (Megapodius freycinet Gaimard) Pada Areal Persarangan Pesisir Pantai dan Hutan Dataran Rendah Pulau Rumberpon.Seminar Hasil Magang, Kursus, dan Penelitian. Unit Pelayanan MIPA. Faperta UNCEN Manokwari, 115-120

Petocz, R.G. 1987. Konservasi Alam dan Pembangunan di Irian Jaya. Pustaka Graffiti Press Jakarta.hal 163

Refisch, J. and Koné, I. 2005. Impact of commercial hunting on monkey populations in the Taï region, Côte d'Ivoire. Biotropica 37(1), 136-144

Robinson, J.G. and Bennett, E.L. (Eds.). 2000. Hunting for sustainability in Tropical Forests. New York: Columbia University Press. Milner-Gulland et al., 2003;

Robinson, J.G., Redford, K.H. and Bennett, E.L. 1999. Wildlife harvest in logged tropical forests. Science 284, 595596

Steidl, R.J. and Anthony, R.G. 2000. Experimental effects of human activity on breeding bald eagles. Ecol. App. 10: 258-268.

Swarthout, E. and Steidl, R.J. 2003. Experimental effects of hiking on Mexican spotted owls. Conserv Biol 17: 307-315.

Triyantoro, S. 2002. Tingkat Konsumsi dan Teknik Berburu Burung Maleo (Megapodius freycinet) oleh Penduduk Desa Bremi, Yoom Nuni dan Saubeba Kecamatan Manokwari. Skripsi, Universitas Negeri Papua., Manokwari.

Tuhumury, A. A. t.t. Rencana Pengelolaan Satwa Burung Maleo/Momoa (Eulipoa Wallace) Di Maluku.Dosen Jurusan Kehutanan Fakultas PertanianUnpatti. www.kewang-haruku.com 